\title{
Targeting Radiotherapy to Cancer by Gene Transfer
}

\author{
R. J. Mairs* and M. Boyd \\ Targeted Therapy Group, Cancer Research UK Beatson Laboratories, Garscube Estate, \\ Glasgow G61 1BD, Scotland, UK
}

Received 7 July 2002; accepted 19 July 2002

\begin{abstract}
Targeted radionuclide therapy is an alternative method of radiation treatment which uses a tumor-seeking agent carrying a radioactive atom to deposits of tumor, wherever in the body they may be located. Recent experimental data signifies promise for the amalgamation of gene transfer with radionuclide targeting. This review encompasses aspects of the integration of gene manipulation and targeted radiotherapy, highlighting the possibilities of gene transfer to assist the targeting of cancer with low molecular weight radiopharmaceuticals.
\end{abstract}

\section{INTRODUCTION}

While tumors which are confined to their site of origin may often be cured by local treatment such as surgery or conventional external beam irradiation, cancer which has spread to locations distant from the primary tumor requires a treatment which is applied to the whole body of the patient. Total body irradiation is effective in the management of leukemia but normal tissue intolerance restricts the radiation dose which can be given, so that it cannot be used against less radiosensitive neoplasia. $\mathrm{Bi}$ ologically targeted radionuclide therapy is an alternative method of systemic irradiation treatment which circumvents the two problems of widespread distribution of disease and the intolerance of normal tissues.

Targeted radiotherapy uses a molecular vehicle which either localises on the surface of malignant cells or is preferentially accumulated within them. For many tumours, monoclonal antibodies or their fragments represent the only targeting agents. With the notable exception of Bcell lymphoma [1,2], clinical applications of these radiolabelled macromolecules have generally been unsatisfactory due to low tumor specificity of targeted epitopes, limited penetration into tumors, and the provocation of anti-mouse immunoglobulin responses. These considerations favour the use of nonimmunogenic small molecules with higher uptake in tumours. These criteria are fulfilled by peptides, meta-iodobenzylguanidine (MIBG), and sodium iodide $(\mathrm{NaI})$, which are readily available in radioiodinated form. MIBG and NaI have been used extensively for the treatment of neural crest-derived tumors (neuroblastoma and phaeochromocytoma) and thyroid carcinoma, respectively.

The new challenge is to enhance targeted radiotherapy by combining it with the transfer into tumour cells of genes encoding specific transporters. The success of this approach has been demonstrated in model systems. Efforts are now underway to optimise tumour to normal tissue uptake ratios; to limit the expression of transporter genes to malignant sites; and to compare the therapeutic potential of $\alpha$ - and $\beta$-emitting radionuclides conjugated to tumour-seeking agents. These investigations will determine optimal promoter/transgene/radionuclide combinations for effective human anticancer gene therapy.

\section{TRANSDUCTION OF ANTIGEN ENCODING GENES FOR ANTIBODY TARGETING}

The efficacy of radiolabelled antibodies is not due to radiation kill alone [3] but results also from the cytotoxic effects of unlabelled antibody, namely apoptosis, complement-mediated cytolysis and antibody-dependent cellular cytotoxicity. This type of treatment is proving to be useful in the management of B-cell lymphomas [4] which are more radiosensitive than solid tumours. They have a propensity to apoptose after radiation insult and have limited capacity for the repair of sublethal damage. However, radioimmunotherapy of other tumour types has been less impressive. An average value, computed from a wide range of articles, for the accumulation of radiolabelled antibodies- $0.005 \%$ per gram of the administered activity—is insufficient for tumour sterilisation [5]. An impediment to radioimmunotherapy is the sparsity of antigen presentation on the membranes of tumour cells.

This problem has been addressed by transfection of genes to induce tumour cells to express high concentrations of membrane-associated epitopes which have affinity for monoclonal antibodies. Radiolabelled antibodies directed against carcinoembryonic antigen (CEA) have 
been used extensively in experimental and clinical detection and treatment of various tumours (reviewed by Buchsbaum and Curiel [6]). Raben et al [7] have demonstrated that adenovirus-mediated gene transfer resulted in high levels of CEA expression in vitro in tumour cells that did not constitutively express CEA, rendering those cells capable of binding radiolabelled COL-1 anti-CEA antibody. They have further demonstrated the applicability of this approach in vivo in nude mice resulting in enhanced, radiolabelled, antibody localisation to tumours transduced by intratumoural injection of the recombinant virus.

After extensive preclinical testing, the most exciting clinical data has come from the use of radioimmunotherapy in the treatment of lymphoma and haematological malignancies and it would now appear highly likely that radioimmunotherapy in combination with gene transfer will play a major role in treatment strategies for these diseases. Results in solid tumours are improving. However, much progress remains to be made before RIT becomes a component of standard practice for common malignancies in the clinic.

\section{FACILITATION OF PEPTIDE TARGETING BY RECEPTOR GENE EXPRESSION}

Tumour-targeting peptides offer several advantages over antibodies such as improved penetration characteristics, ease of labelling, and lack of immunogenicity. Several studies show the feasibility of inducing the expression of receptors by tumour cells to improve the accumulation of toxic radionuclides transported by a variety of peptide ligands. For example, virus-assisted gene transfer stimulated the expression of the receptor for thyrotropinreleasing hormone (TRH) with subsequent binding of radiolabelled TRH [8]. Unfortunately, this tripeptide has a short biological half-life in serum and loses receptor affinity after conjugation to radionuclides. Using in vitro and in vivo models, Rogers et al [9] have demonstrated the potential of a seven-peptide analogue of bombesin to target tumour cells transfected with the gene encoding gastrin releasing peptide receptor. This ligand is attractive because it is readily bound to several different radionuclides, maintains receptor binding affinity and exhibits in vivo stability. Recently, Stackhouse et al [10] introduced a greater level of sophistication to this scheme by placing the expression of the GPR transgene under the control of promoter elements of one of two different genes-erbB-2 and $M U C 1$ - which are overexpressed in a number of tumours. This strategy was successful in restricting GPR expression to human breast and cholangiocarcinoma cell lines thereby demonstrating the potential for tumour-specific targeting with radiolabelled peptide. An exciting application of the control of expression by the MUC1 carcinoma-promoter has been described by Chen et al [11]. They eliminated six logs of contaminating cancer cells from haemopoietic stem cell preparations by ganciclovir treatment after adenoviral-mediated transduction of HSV-tk gene under control of the MUC1 promoter. This study illustrates the potential of the gene transfer approach to the purging of marrow or peripheral blood stem cells.

An attractive means of improving the specificity of targeting is to express a nonhuman receptor on tumour cells and target these with a xenogeneic molecule. For example, the murine glycoprotein, interleukin-4 (IL-4), does not bind to the human IL-4 receptor nor does the human IL-4 have affinity for the murine receptor. The mouse receptor cDNA has been expressed in heterologous cells, resulting in a five-fold increase in binding of ligand to transfectants [12]. It is hoped that this promising strategy for the transport of therapeutic radionuclides can be developed using xenogeneic systems which involve smaller targeting agents such as peptides or steroids [13].

Somatostatin receptors, which are expressed on many tumours of neuroendocrine origin, constitute another peptide target which may be exploitable for radionuclide therapy. Octreotide is an octapeptide analogue of somatostatin which has greater stability in plasma than the natural ligand [14]. Rogers et al [15] recently employed recombinant adenoviral vectors to induce somatostatin receptors on human nonsmall cell lung cancer cells which were grown as xenografts. Tumour localisation was demonstrated using $\left[{ }^{111} \mathrm{In}\right]$-labelled octreotide and therapeutic efficacy was obtained with $\left[{ }^{90} \mathrm{Y}\right]$ octreotide. This is the first illustration in vivo of the effectiveness of a radiolabeled peptide targeted to a receptor expressed on the surface of tumor cells following gene transfer. It is expected that these studies will form the basis of future therapeutic investigations using gene transfer to enhance tumour targeting by radiolabelled octreotide.

\section{RADIOHALIDE CONCENTRATION VIA THE SODIUM IODIDE SYMPORTER}

Unlike the above schemes for radionuclide targeting, sodium radioiodide $\left(\mathrm{Na}^{131} \mathrm{I}\right)$ therapy requires no radiochemical synthetic procedure. Most well-differentiated thyroid tumours retain iodide-concentrating capacitymediated by the sodium (Na) iodide (I) symporter (NIS). Therefore, $\mathrm{Na}^{131} \mathrm{I}$ is used to ablate postsurgical remnants and to treat recurrent and metastatic disease. The overall prognosis following radioiodine therapy is good for differentiated thyroid cancer. This is the most basic, yet most efficacious form of radionuclide therapy to date.

Cloning and characterisation of the sodium iodide symporter (NIS) gene has stimulated cytoreductive gene therapy based on NIS gene transfer followed by the administration of radioiodide. Transfer of the NIS gene into a variety of nonthyroidal cancer cell lines has induced iodide uptake activity and cytotoxicity $[16,17,18]$. Following PSA promoter-mediated NIS gene delivery, prostatespecific iodide accumulation was achieved in prostate cancer cells that was sufficient to attain a therapeutic 
response of ${ }^{131} \mathrm{I}$ in vitro and in vivo $[19,20]$. These observations indicate that, following thyroid blockade, it may be possible to deliver $\mathrm{Na}^{131}$ I to transfected, NISexpressing, tumour cells with minimal uptake of radioactivity in normal tissues.

However, rapid efflux of radioiodide from NIS gene transfectants imposes a severe limitation on tumor cell killing. Means of circumventing this problem are under investigation. Unlike NIS-transfected tumor cells, thyrocytes exhibit, in addition, peroxidase activity which is responsible for the oxidation of accumulated iodide, leading to its conjugation to tyrosyl residues of thyroglobulin and prolonged entrapment within the cell. Huang et al [21] reported an increase in radioiodide uptake and retention and enhanced apoptosis in nonsmall cell lung cancer cells transfected with both NIS and thyroperoxidase genes.

As well as iodide, several other monovalent anions have the affinity for NIS [22]. Those with ionic radii similar to iodide are more readily transported [23]. Of special interest are $\left[{ }^{211} \mathrm{At}^{-}\right]$astatide for therapy and pertechnetate $\left({ }^{99} \mathrm{~m} \mathrm{TcO}_{4}{ }^{-}\right)$for imaging.

The choice of therapeutic radionuclide (Table 1) is influenced by the expected intracellular residence time of the radioactivity and the range of cross fire radiation needed to sterilise clumps of tumor cells of different sizes. Ideally, the physical half-life of the radionuclide should closely match its intracellular half-time of retention. Therefore, an alternative tactic to overcome the rapid efflux of iodide from NIS transfectants is to employ radiohalides with short $t_{1 / 2}$ values. Experimental evidence indicates that the highly radiotoxic $\alpha$-emitter astatide $\left(\mathrm{Na}^{211} \mathrm{At}\right)$ has an affinity for NIS-expressing cells [24] and could be an alternative radiohalide to $\left[{ }^{131} \mathrm{I}\right]$ iodide for NIS-based endoradiotherapy.

The demonstration that NIS was expressed not only in the lactating mammary gland but also in more than $80 \%$ of breast cancer [25] indicated that radioiodide may be an option for the diagnosis and treatment of mammary gland malignancies. To assess the feasibility of imaging NIS-expressing tumors, we compared the rate of loss of actively transported ${ }^{131} \mathrm{I}$ and ${ }^{99} \mathrm{~m} \mathrm{TcO}_{4}{ }^{-}$in transduced UVW human glioma cells (Figure 1). The enhanced retention of ${ }^{99} \mathrm{~m}^{\mathrm{TcO}_{4}}{ }^{-}$suggested its utility for scintigraphic localisation of tumors after NIS-transfection. Recently, Moon et al [26] established a correlation between the expression of NIS mRNA and the uptake of ${ }^{99} \mathrm{~m} \mathrm{TcO}_{4}{ }^{-}$ in 25 breast tumors. Because of its chemical similarity to pertechnetate, the perrhenate anion $\left({ }^{188} \mathrm{ReO}_{4}{ }^{-}\right)$is also concentrated by NIS-positive cells. ${ }^{188} \mathrm{ReO}_{4}{ }^{-}$could be a potent therapeutic agent because it is able to deliver a dose 4.5 times higher than ${ }^{131}$ I [27].

Exploitation of the NIS has potentially important applications in the management of breast cancer and other tumor types. Future directions in NIS-targeting will include the enhancement of radiohalide retention in tumors, circumvention of normal tissue uptake by differential regulation of NIS expression, and the investigation of tumor-imaging agents.
TABLE 1. Radiohalogens for targeted radiotherapy.

\begin{tabular}{lccr}
\hline Radionuclide & Half-life & Emitted particles & Particle range \\
\hline${ }^{131} \mathrm{I}$ & $8 \mathrm{~d}$ & $\beta$ & $0.8 \mathrm{~mm}$ \\
${ }^{125} \mathrm{I}$ & $60 \mathrm{~d}$ & Auger electrons & $\sim 10 \mathrm{~nm}$ \\
${ }^{123} \mathrm{I}$ & $13 \mathrm{~h}$ & Auger electrons & $\sim 10 \mathrm{~nm}$ \\
${ }^{211} \mathrm{At}$ & $7 \mathrm{~h}$ & $\alpha$ & $0.05 \mathrm{~mm}$ \\
\hline
\end{tabular}

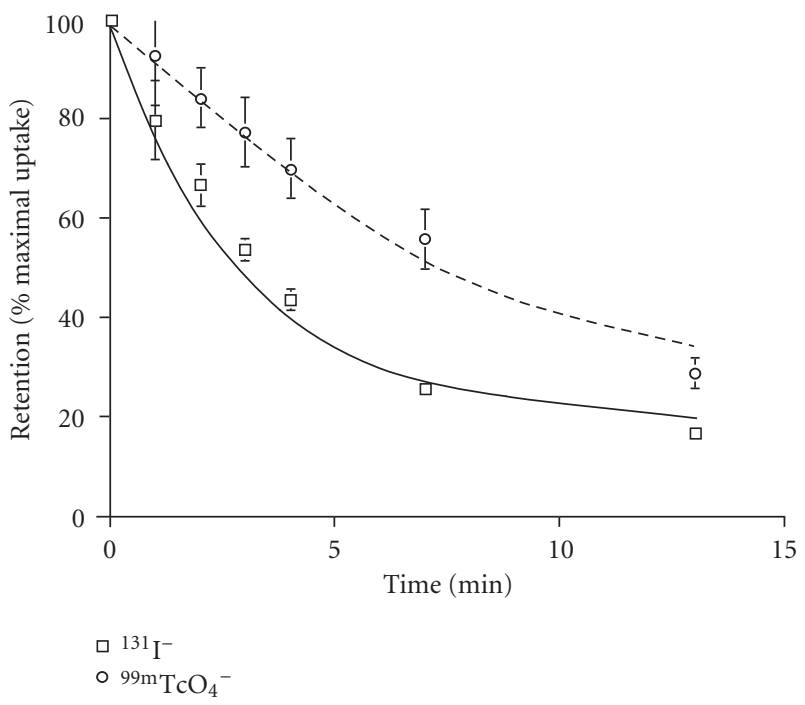

FIgURE 1. Rate of iodide efflux from UVW-hNIS cells. $10^{6}$ cells were incubated with $7 \mathrm{kBq} / \mathrm{ml} \mathrm{Na}^{131} \mathrm{I}$ or $\mathrm{Na}^{99} \mathrm{~m}^{\mathrm{TcO}_{4}}{ }^{-}$for 1 hour. The radioactive solution was replaced with fresh medium which was removed at various intervals for measurement of activity by gamma counting. Each point represents the mean and S.D. of three experiments performed in triplicate. Intracellular halftimes of retention: ${ }^{131} \mathrm{I}=3 \mathrm{~min} ;{ }^{99} \mathrm{mcO}_{4}{ }^{-}=8 \mathrm{~min}$.

\section{TRANSFECTION OF THE NORADRENALINE TRANSPORTER GENE FOR MIBG- TARGETED RADIOTHERAPY}

One impediment to the wider application of radioiodide therapy is the localisation of radioactivity in nontarget organs. This has prompted the search for tumoraffinic radiolabelled compounds which have a low tendency to deiodinate in vivo. One such agent is $\left[{ }^{131} \mathrm{I}\right]$ labelled meta-iodobenzylguanidine ([$\left.\left.{ }^{131} \mathrm{I}\right] \mathrm{MIBG}\right)$. The structure of MIBG is based on those of the adrenergic neurone blockers guanethidine and bretylium [28] (Figure 2). Because MIBG has high affinity for the noradrenaline transporter (NAT) [29], it is used in the imaging and treatment of tumors derived from the neural crest, such as neuroblastoma and phaeochromocytoma. NAT expression is predictive for MIBG uptake capacity [30] and quantification of NAT mRNA could be used for the selection of patients for MIBG therapy [31].

Approximately $15 \%$ of neuroblastoma patients are MIBG negative by scintigraphy and therefore do not progress to $\left[{ }^{131} \mathrm{I}\right] \mathrm{MIBG}$ therapy. Moreover, $\left[{ }^{131} \mathrm{I}\right] \mathrm{MIBG}$ 


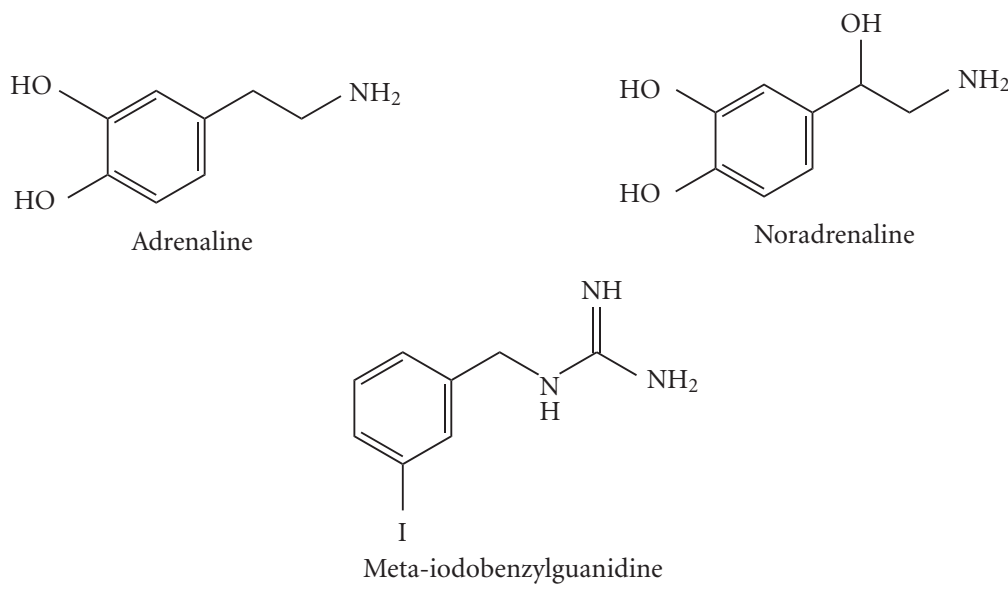

(MIBG)
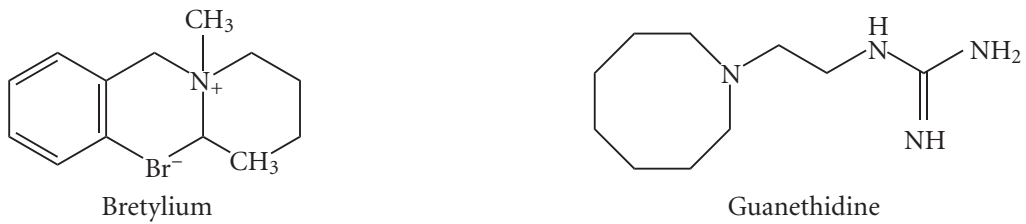

FIGURE 2. Catecholamines, adrenergic neurone blockers, and MIBG.

uptake in malignant sites is heterogeneous [32], suggesting that this therapy alone is unlikely to cure advanced stage disease. Our efforts to increase MIBG accumulation in malignant cells have considered means of enhancing NAT gene transcription. Recently, we have transfected the NAT gene into neuroblatoma cells, resulting in stimulated MIBG uptake. Transfectants more readily succumbed in a dose-dependent manner to treatment with $\left[{ }^{131} \mathrm{I}\right] \mathrm{MIBG}$ [33]. While presently, there is only an in vitro demonstration of the effect, these results are promising and indicate that it may be possible to elevate the intracellular levels of the radiopharmaceutical so that cure, rather than temporary control of tumour growth, could be the outcome. Given an appropriate delivery vehicle and tumour-specific control of expression, the introduction of exogenous NAT may make more neuroblastoma tumours amenable to MIBG therapy. In collaboration with the Gaslini Institute, Genoa, we are currently developing immunoliposomal systems for the delivery to neuroblastoma of NAT cDNA and MIBG. $\left[{ }^{131} \mathrm{I}\right] \mathrm{MIBG}$ is one of the best agents for targeted radiotherapy but its utility is restricted to a small number of NAT-expressing tumour types. We observed that after transfection of the NAT gene into a human glioma cell line, it actively concentrated $\left[{ }^{131} \mathrm{I}\right] \mathrm{MIBG}$ resulting in substantial toxicity, demonstrating the potential of gene therapy-assisted MIBG-targeted radiotherapy for the treatment of nonneuroectodermal tumors [34]. These findings are extremely encouraging for the development of NAT gene transfer-mediated $\left[{ }^{131} \mathrm{I}\right] \mathrm{MIBG}$ therapy. We expect the first clinical applications to be in the treatment of glioma or prostate carcinoma.
Targeting gene expression specifically to tumour cells, is one of the most important goals of research in cancer gene therapy. Appropriate control elements for the expression of transgenes that facilitate targeted radiotherapy are radiation-inducible gene promoters. Aspects of this type of gene regulation are reviewed by Robson in this issue.

Telomerase is the most common general marker of cancer cells and its activity has been detected in every major category of human malignancy, whereas normal somatic tissues have negligible activity [35, 36, 37, 38]. Therefore, an alternative method of specifying gene expression to malignant cells is provided by the telomerase promoters. Unfortunately, mammalian promoter elements are generally inefficient transcriptional activators [39]. However, we observed 17-fold enhancement of ${ }^{[131}$ I]MIBG uptake by UVW glioma cells transfected with the NAT gene whose expression was driven by the human telomerase RNA (hTR) promoter. This level of induction was $70 \%$ of the uptake achieved by a strong viral promoter and was sufficient to sterilise all clonogens in multicellular spheroids, suggesting that hTR-regulated expression of NAT may be an effective therapeutic strategy [40].

\section{EVALUATION OF RADIOLOGICAL BYSTANDER EFFECTS}

It is unlikely that gene therapy technology will achieve $100 \%$ transfection of cells in a clinical tumour. Bystander effects are therefore an important requirement for effective gene therapy. Current gene therapy is mostly based 


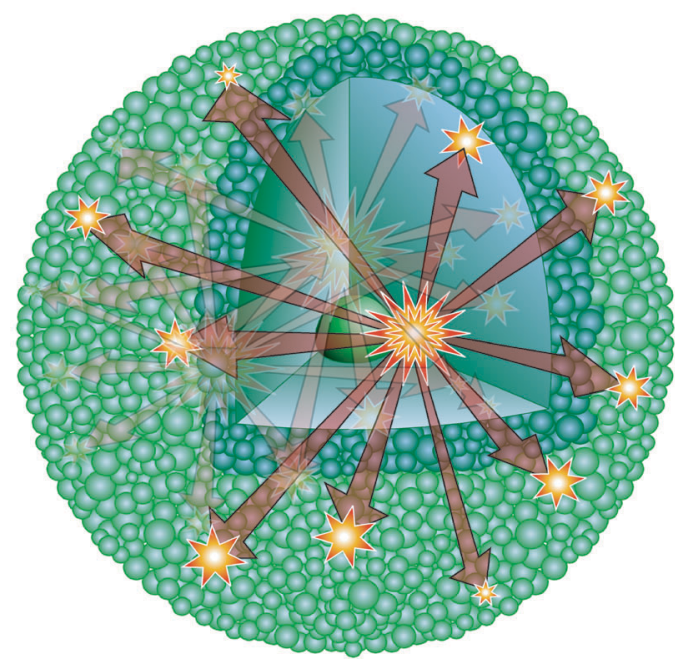

Figure 3. Radiation cross fire. An advantage of the concentration in tumor cells of radionuclides with long-range emissions (eg, ${ }^{131} \mathrm{I}$ ) is the presence of a radiological bystander effect. That is the bombardment of untargeted cells by beta decay particles emanating from neighbouring, successfully targeted cells which have actively accumulated ${ }^{131}$ I-labelled drug.

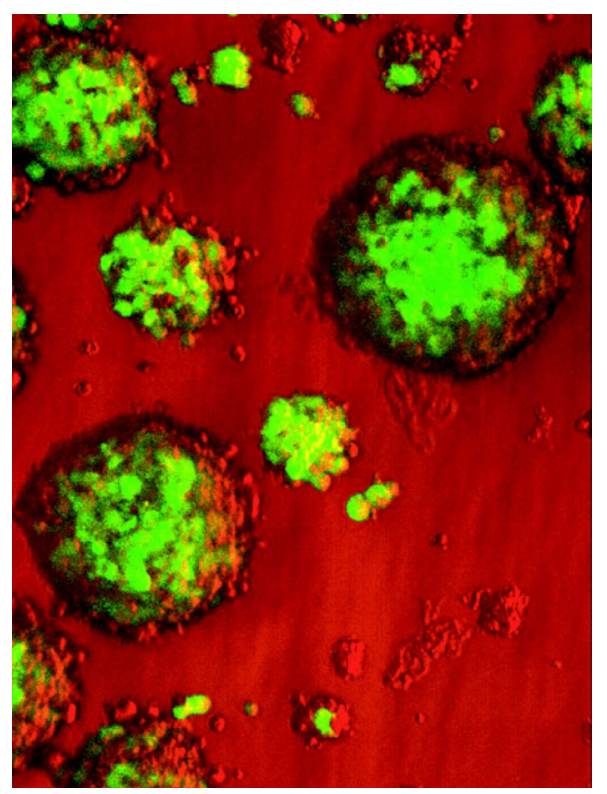

FIgURe 4. Transfectant mosaic spheroids. These multicellular spheroids were prepared by mixing human glioma cells (UVW) with UVW cells transfected with the gene encoding the jellyfish green fluorescent protein (GFP). The GFP can be used as a marker for the transfer of therapeutically useful genes such as those encoding receptors for targeting agents. Spheroids composed of a range of proportions of transfected to untransfected cells allow the determination of the influence of gene transfer efficiency upon the efficacy of targeted radiotherapy.

on prodrug activation, with bystander effects dependent on gap junctions which often diminish with tumour progression [41]. Novel systems providing a freely diffusable product are under investigation [42].

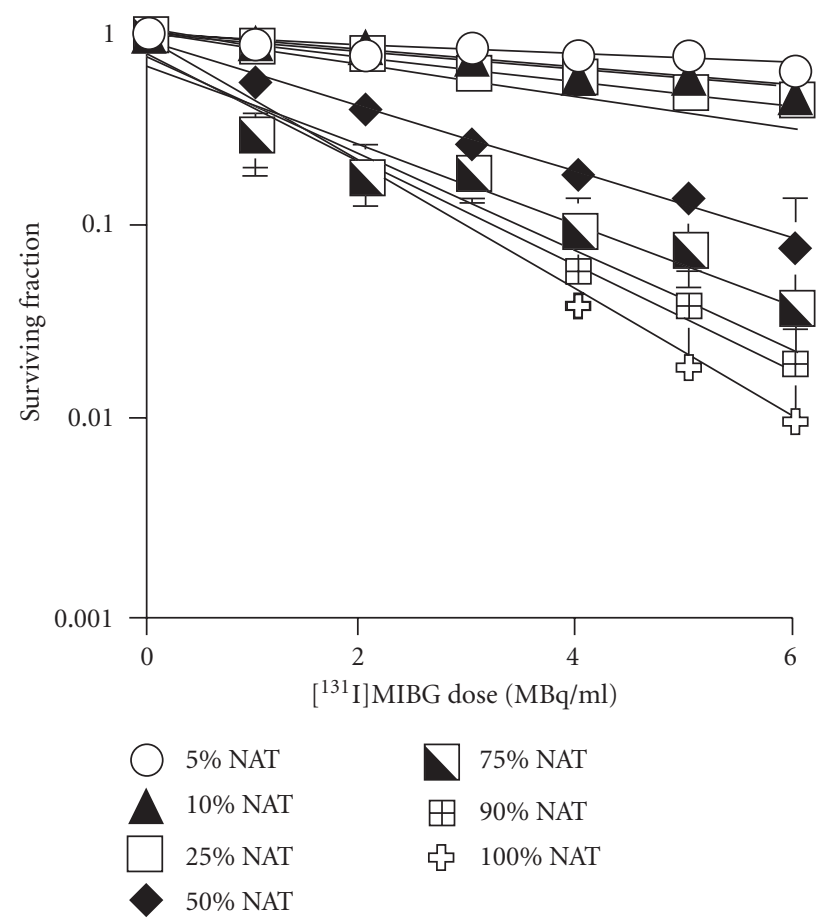

FIgURE 5. The effect on clonogenic survival of TMS treated with $\left[{ }^{131} \mathrm{I}\right] \mathrm{MIBG}$. TMS composed of various proportions of NAT-expressing cells were assessed for clonogenic potential after administration of $\left[{ }^{131} \mathrm{I}\right] \mathrm{MIBG}$. Spheroids were treated with 0 to $6 \mathrm{MBq} / \mathrm{ml}$ of $\left[{ }^{131} \mathrm{I}\right] \mathrm{MIBG}$ before washing and leaving intact for 24 hours to allow radiation cross fire to occur. The various spheroid groups were then disaggregated to single cells and seeded for clonogenic survival. The data is mean values of three experiments with error bars showing standard deviations.

Multicellular spheroids are substantially more susceptible than monolayer cultures to the lethal effects of ${ }^{131} \mathrm{I}$ $\beta$-radiation [43]. The increased effectiveness of radionuclide treatment of cellular aggregates is due to the enhanced efficiency of absorption of decay energy in threedimensional cultures $[34,44]$. This cross fire irradiation phenomenon (Figure 3 ) is an especially attractive feature of gene therapy schemes involving cellular concentration of radionuclides since gene transfer is notoriously inefficient, necessitating a mechanism which achieves bystander cell kill. The radiological bystander effect resulting from radiation cross fire provides exciting new possibilities, especially when transfection rates are low. This and other bystander effects require further investigation, for which a suitable experimental model would be very valuable.

Very recently, we have developed a modified spheroid system-transfectant mosaic spheroids (TMS) [45] which is well suited to the experimental investigation of bystander effects (Figure 4). TMS are hybrids formed by coculturing gene-transfected and nontransfected (but otherwise identical) cells in controlled proportions. This allows the experimental simulation of small tumours in which a range of proportions of cells have been 
transfected. The mosaic spheroid model is used in our investigation of the radiological bystander effect to quantify the effects of radiation cross fire as a function of the proportion of the cells transfected.

To examine the utility of this system, we prepared TMS from glioma cells transfected with the NAT gene or the GFP gene. Cell killing by $\left[{ }^{131} \mathrm{I}\right] \mathrm{MIBG}$ was proportional to the percentage of MIBG-uptaking cells (Figure 5). We conclude that TMS provide a useful model for assessment of the effectiveness of targeted radiotherapy in combination with gene therapy when less than $100 \%$ of the target cell population is expressing the NAT transgene [46].

\section{CONCLUSION}

Despite the attractiveness of the concept of sterilising cancer cells by means of the specific delivery of radionuclides, targeted radiotherapy has been applied only to a few malignant diseases with suitable biochemical features. The advent of gene transfer technology, promises to widen the scope of targeted radiotherapy by enabling the expression by tumour cells of membrane-bound proteins which actively accumulate radiopharmaceuticals.

Recent research findings augur well for the development of gene transfer to enable the targeting of a variety of tumour types with low molecular weight radiopharmaceuticals. It is envisaged that this approach combined with conventional therapeutic modalities, will improve cancer treatment in the new century. The immediate goals are to achieve efficient, tumour-specific, gene expression and efficacy in animal models before proceeding to clinical evaluation.

We envisage that the first clinical usage of this combined approach will be for the treatment of regionally confined malignancies such as glioma and bladder carcinoma or for the purging of bone marrow or peripheral blood stem cells prior to autologous rescue. To turn these dreams into reality, we must now develop efficient and specific vectors for the delivery of therapeutic transgenes.

\section{REFERENCES}

[1] Kaminski MS, Estes J, Zasadny KR, et al. Radioimmunotherapy with iodine (131)I tositumomab for relapsed or refractory B-cell non-Hodgkin lymphoma: updated results and long- term follow-up of the University of Michigan experience. Blood. 2000; 96(4):1259-1266.

[2] Kaminski MS, Zelenetz AD, Press OW, et al. Pivotal study of iodine I 131 tositumomab for chemotherapy-refractory low-grade or transformed low-grade B-cell non-Hodgkin's lymphomas. J Clin Oncol. 2001;19(19):3918-3928.

[3] Illidge T, Honeychurch J, Vandersteen A, Cragg M. Radioimmunotherapy in the pi-BCL1 B cell lymphoma model: efficacy depends on more than targeted irradiation alone. Cancer Biother Radiopharm. 2000;15(6):581-591.
[4] Press OW, Rasey J. Principles of radioimmunotherapy for hematologists and oncologists. Semin Oncol. 2000;27(6 Suppl 12):62-73.

[5] Vaughan AT, Anderson P, Dykes PW, Chapman CE, Bradwell AR. Limitations to the killing of tumours using radiolabelled antibodies. $\mathrm{Br} J$ Radiol. 1987; 60(714):567-572.

[6] Buchsbaum DJ, Curiel DT. Gene therapy for the treatment of cancer. Cancer Biother Radiopharm. 2001;16(4):275-288.

[7] Raben D, Buchsbaum DJ, Khazaeli MB, et al. Enhancement of radiolabeled antibody binding and tumor localization through adenoviral transduction of the human carcinoembryonic antigen gene. Gene Ther. 1996;3(7):567-580.

[8] Buchsbaum DJ, Raben D, Stackhouse MA, et al. Approaches to enhance cancer radiotherapy employing gene transfer methods. Gene Ther. 1996;3(12):10421068.

[9] Rogers BE, Rosenfeld ME, Khazaeli MB, et al. Localization of iodine-125-mIP-Des-Met14-bombesin (7-13) NH2 in ovarian carcinoma induced to express the gastrin releasing peptide receptor by adenoviral vector-mediated gene transfer. J Nucl Med. 1997; 38(8):1221-1229.

[10] Stackhouse MA, Buchsbaum DJ, Kancharla SR, et al. Specific membrane receptor gene expression targeted with radiolabeled peptide employing the erbB2 and DF3 promoter elements in adenoviral vectors. Cancer Gene Ther. 1999;6(3):209-219.

[11] Chen L, Pulsipher M, Chen D, et al. Selective transgene expression for detection and elimination of contaminating carcinoma cells in hematopoietic stem cell sources. J Clin Invest. 1996;98(11):25392548.

[12] Curiel DT. High-efficiency gene transfer employing adenovirus-polylysine-DNA complexes. Nat Immun. 1994;13(2-3):141-164.

[13] Romano G, Pacilio C, Giordano A. Gene transfer technology in therapy: current applications and future goals. Oncologist. 1998;3(4):225-236.

[14] Katzenellenbogen JA, Coleman RE, Hawkins RA, et al. Tumor receptor imaging: proceedings of the National Cancer Institute workshop, review of current work, and prospective for further investigations. Clin Cancer Res. 1995;1(8):921-932.

[15] Rogers BE, Zinn KR, Lin CY, Chaudhuri TR, Buchsbaum DJ. Targeted radiotherapy with [(90)Y]-SMT 487 in mice bearing human nonsmall cell lung tumor xenografts induced to express human somatostatin receptor subtype 2 with an adenoviral vector. Cancer. 2002;94(suppl 4):1298-1305.

[16] Mandell RB, Mandell LZ, Link CJ Jr. Radioisotope concentrator gene therapy using the sodium/iodide symporter gene. Cancer Res. 1999;59(3):661-668.

[17] Boland A, Ricard M, Opolon P, et al. Adenovirusmediated transfer of the thyroid sodium/iodide 
symporter gene into tumors for a targeted radiotherapy. Cancer Res. 2000;60(13):3484-3492.

[18] Carlin S, Cunningham SH, Boyd M, McCluskey AG, Mairs RJ. Experimental targeted radioiodide therapy following transfection of the sodium iodide symporter gene: effect on clonogenicity in both two-and three-dimensional models. Cancer Gene Ther. 2000; 7(12):1529-1536.

[19] Spitzweg C, O'Connor MK, Bergert ER, Tindall DJ, Young CY, Morris JC. Treatment of prostate cancer by radioiodine therapy after tissue-specific expression of the sodium iodide symporter. Cancer Res. 2000;60(22):6526-6530.

[20] Spitzweg C, Dietz AB, O'Connor MK, et al. In vivo sodium iodide symporter gene therapy of prostate cancer. Gene Ther. 2001;8(20):1524-1531.

[21] Huang M, Batra RK, Kogai T, et al. Ectopic expression of the thyroperoxidase gene augments radioiodide uptake and retention mediated by the sodium iodide symporter in non-small cell lung cancer. Cancer Gene Ther. 2001;8(8):612-618.

[22] Eskandari S, Loo DD, Dai G, Levy O, Wright EM, Carrasco N. Thyroid Na +/I- symporter. Mechanism, stoichiometry, and specificity. J Biol Chem. 1997;272(43):27230-27238.

[23] Halmi NS. Thyroidal iodide transport. Vitam Horm. 1961;19:133-163.

[24] Carlin S, Mairs RJ, Welsh P, Zalutsky MR. Sodiumiodide symporter (NIS)-mediated accumulation of $\left[{ }^{211} \mathrm{At}\right]$ astatide in NIS-transfected human cancer cells. Nucl Med Biol. 2002;29(7):729-739.

[25] Tazebay UH, Wapnir IL, Levy O, et al. The mammary gland iodide transporter is expressed during lactation and in breast cancer. Nat Med. 2000;6(8):871878.

[26] Moon DH, Lee SJ, Park KY, et al. Correlation between 99mTc-pertechnetate uptakes and expressions of human sodium iodide symporter gene in breast tumor tissues. Nucl Med Biol. 2001;28(7):829834.

[27] Dadachova E, Bouzahzah B, Zuckier LS, Pestell RG. Rhenium-188 as an alternative to Iodine131 for treatment of breast tumors expressing the sodium/iodide symporter (NIS). Nucl Med Biol. 2002;29(1):13-18.

[28] Wieland DM, Wu J, Brown LE, Mangner TJ, Swanson DP, Beierwaltes WH. Radiolabeled adrenergi neuron-blocking agents: adrenomedullary imaging with $\left[{ }^{131} \mathrm{I}\right]$ iodobenzylguanidine. J Nucl Med. 1980; 21(4):349-353.

[29] Jaques S Jr, Tobes MC, Sisson JC, Baker JA, Wieland DM. Comparison of the sodium dependency of uptake of meta-lodobenzylguanidine and norepinephrine into cultured bovine adrenomedullary cells. Mol Pharmacol. 1984;26(3):539-546.

[30] Mairs RJ, Livingstone A, Gaze MN, Wheldon TE, Barrett A. Prediction of accumulation of ${ }^{131} \mathrm{I}-$ labelled meta-iodobenzylguanidine in neuroblas- toma cell lines by means of reverse transcription and polymerase chain reaction. Br J Cancer. 1994;70(1): 97-101.

[31] Mairs RJ. Neuroblastoma therapy using radiolabelled $\left[{ }^{131} \mathrm{I}\right]$ meta-iodobenzylguanidine ([$\left.\left.{ }^{131} \mathrm{I}\right] \mathrm{MIBG}\right)$ in combination with other agents. Eur $J$ Cancer. 1999;35(8):1171-1173.

[32] Moyes JSE, Babich JW, Carter R, Meller ST, Agrawal M, McElwain TJ. Quantitative study of radioiodinated metaiodobenzylguanidine uptake in children with neuroblastoma: correlation with tumor histopathology. J Nucl Med. 1989;30(4):474-480.

[33] Cunningham SH, Boyd M, Brown MM, et al. A gene therapy approach to enhance the targeted radiotherapy of neuroblastoma. Med Pediatr Oncol. 2000; 35(6):708-711.

[34] Boyd M, Cunningham SH, Brown MM, Mairs RJ, Wheldon TE. Noradrenaline transporter gene transfer for radiation cell kill by $\left[{ }^{131} \mathrm{I}\right]$ metaiodobenzylguanidine. Gene Ther. 1999;6(6):11471152.

[35] Kim NW, Piatyszek MA, Prowse KR, et al. Specific association of human telomerase activity with immortal cells and cancer. Science. 1994; 266(5193):2011-2015.

[36] Broccoli D, Young JW, de Lange T. Telomerase activity in normal and malignant hematopoietic cells. Proc Natl Acad Sci USA. 1995;92(20):9082-9086.

[37] Harle-Bachor C, Boukamp P. Telomerase activity in the regenerative basal layer of the epidermis inhuman skin and in immortal and carcinoma-derived skin keratinocytes. Proc Natl Acad Sci USA. 1996; 93(13):6476-6481.

[38] Tahara H, Yasui W, Tahara E, et al. Immunohistochemical detection of human telomerase catalytic component, hTERT, in human colorectal tumor and non-tumor tissue sections. Oncogene. 1999; 18(8):1561-1567.

[39] Chen J, Bezdek T, Chang J, et al. A glial-specific, repressible, adenovirus vector for brain tumor gene therapy. Cancer Res. 1998;58(16):3504-3507.

[40] Boyd M, Mairs RJ, Mairs SC, et al. Expression in UVW glioma cells of the noradrenaline transporter gene, driven by the telomerase RNA promoter, induces active uptake of $\left[{ }^{131} \mathrm{I}\right] \mathrm{MIBG}$ and clonogenic cell kill. Oncogene. 2001;20(53):78047808.

[41] Denning C, Pitts JD. Bystander effects of different enzyme-prodrug systems for cancer gene therapy depend on different pathways for intercellular transfer of toxic metabolites, a factor that will govern clinical choice of appropriate regimes. Hum Gene Ther. 1997;8(15):1825-1835.

[42] Bridgewater JA, Knox RJ, Pitts JD, Collins MK, Springer CJ. The bystander effect of the nitroreductase/CB1954 enzyme/prodrug system is due to a cell-permeable metabolite. Hum Gene Ther. 1997; 8(6):709-717. 
[43] Cunningham SH, Mairs RJ, Wheldon TE, Welsh PC, Vaidyanathan G, Zalutsky MR. Toxicity to neuroblastoma cells and spheroids of benzylguanidine conjugated to radionuclides with short-range emissions. Br J Cancer. 1998;77(12):2061-2068.

[44] Neshasteh-Riz A, Mairs RJ, Angerson WJ, et al. Differential cytotoxicity of [123I]IUdR, [125I]IUdR and $[131 \mathrm{I}] \mathrm{IUUdR}$ to human glioma cells in monolayer or spheroid culture: effect of proliferative heterogeneity and radiation cross-fire. $\mathrm{Br} J$ Cancer. 1998;77(3):385-390.

[45] Boyd, M, Wheldon, TE. Tumour Spheroids in the Culture of Animal Cells. In: Freshney RI, ed. 4th ed. New York, NY: Alan R. Liss; 1999.

[46] Boyd M, Mairs SC, Stevenson K, et al. Transfectant mosaic spheroids: a new model for evaluation of tumour cell killing in targeted radiotherapy and experimental gene therapy. J Gene Med. 2002;4(5):567576.

* Corresponding author. E-mail: r.mairs@beatson.gla.ac.uk Fax: +44 413304127; Tel: +44 413304128 

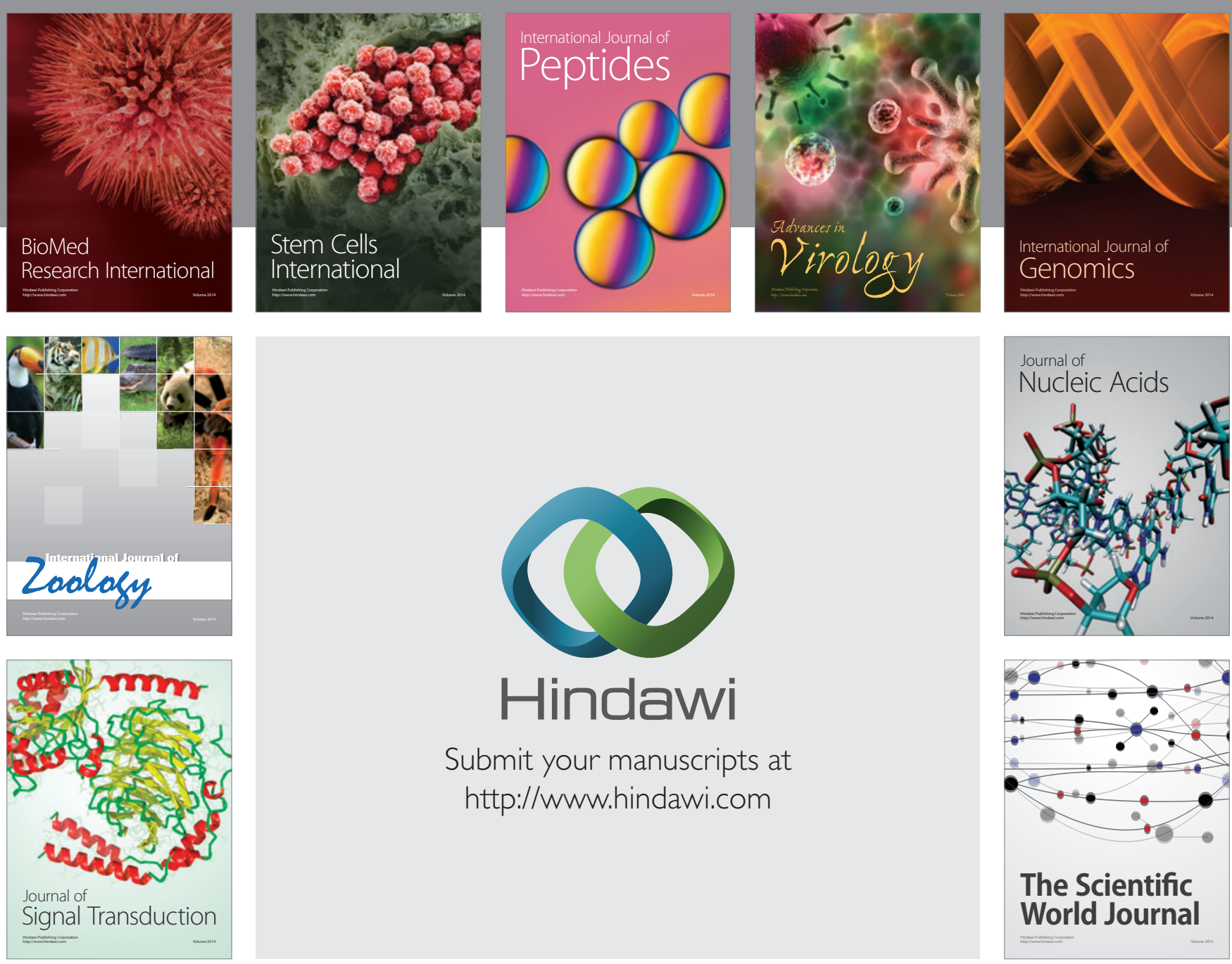

Submit your manuscripts at

http://www.hindawi.com
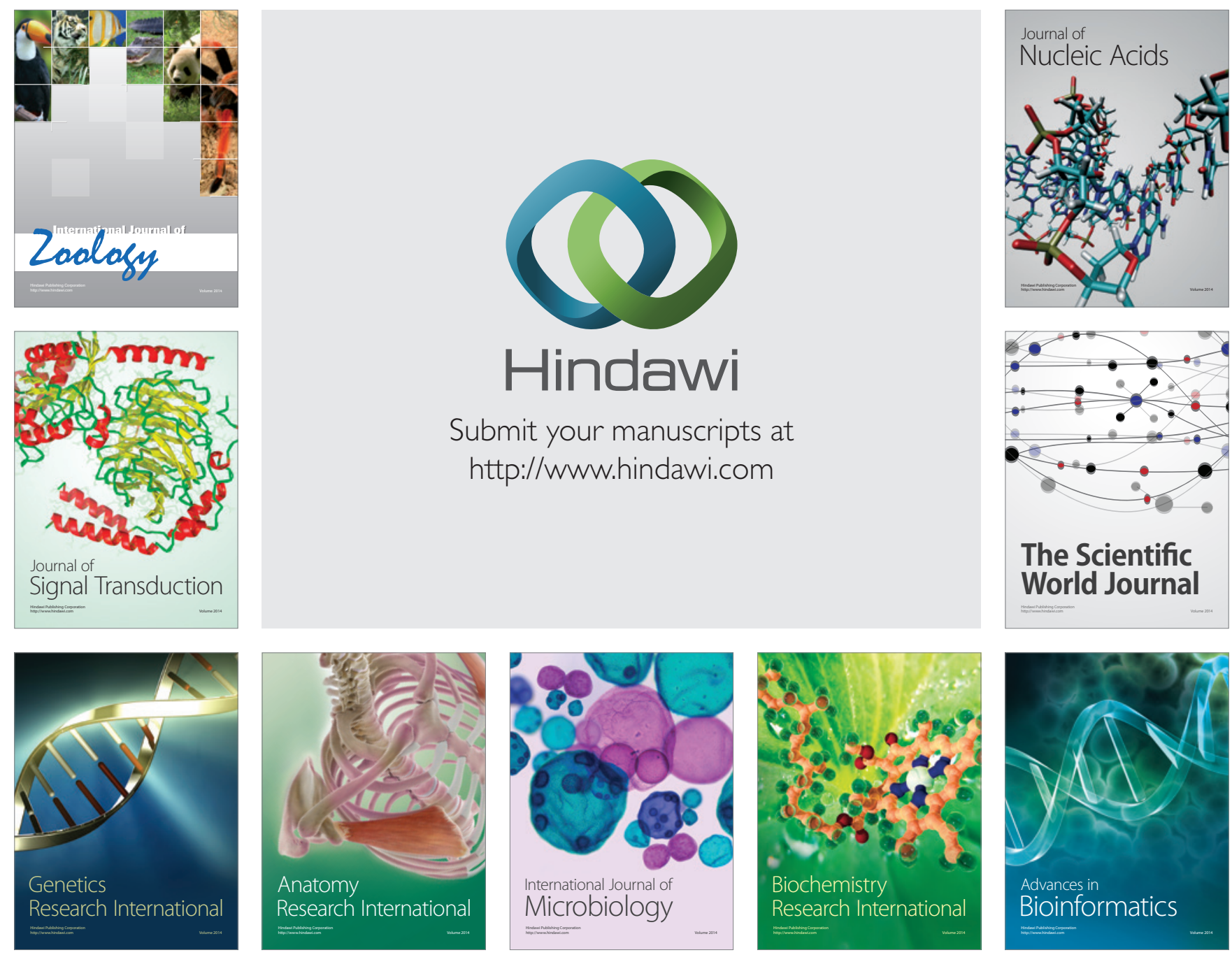

The Scientific World Journal
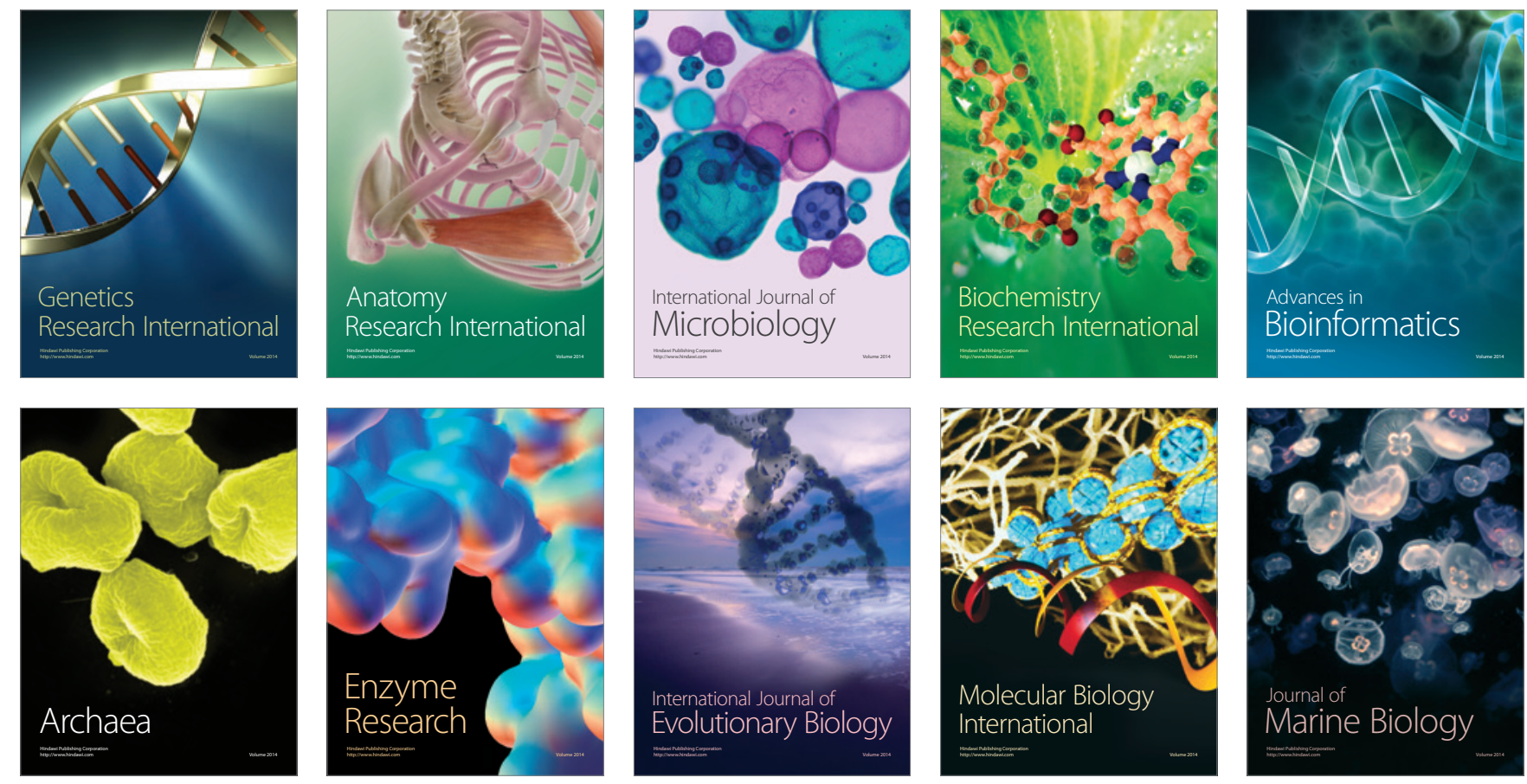